\title{
Pragmatics of Translating Tourism Discourse Texts
}

\author{
Anna Novozhilova ${ }^{1 *}$, Svetlana Korolkova ${ }^{1}$, Yevgenia Shovgenina ${ }^{1}$, and Alexander Shovgenin ${ }^{2}$ \\ ${ }^{1}$ Translation Studies Department, Volgograd State University, Volgograd, Russia \\ ${ }^{2}$ German and Romance Philology Department, Volgograd State University, Volgograd, Russia
}

\begin{abstract}
The article presents translation analysis of the texts within tourism discourse. According to the authors, the Internet is the most popular source of information and thus tourist websites are aimed at forming tourism attractiveness of a certain region as well as promoting regional branding. As illustrated by examples of multilingual hotel websites, the language component of website content is an essential factor for translation. As a result, the analysis of data shows that in many translations various errors are made, which are characterized by a violation of stylistic, lexical, grammatical, spelling and punctuation norms or rules, consequently, translated texts do not correspond to their original communicative and pragmatic function. Having studied the original examples, the authors prove that the translated text in the tourism discourse performs its main function, i.e. attracts a large number of potential customers only when a professional translator while translating generates a new text, taking into account grammatical and linguistic norms of the language of translation, as well as maintaining stylistic imagery and colour in accordance with a specific lingua-culture of a foreign recipient.
\end{abstract}

\section{Introduction}

The tourism industry influences dramatically the interaction and convergence processes among different cultures and nations. Tourism, "despite a series of economic crises and a complex military and political situation, continues to demonstrate the unofficial status of the world phenomenon" [1]. V.A. Mityagina rightly argues that developing in this area today becomes "one of the manifestations of ethnic societies' readiness not only for dialogue and integration, but also for globalization, as the travel activity gives opportunities for approval of co-existence of cultures in their individual experience" [2]. E.Yu. Novikova notes that the tourist sphere is "one of the effective tools for mutual understanding among representatives of various linguacultures, as well as intensification of business and cultural-mediated communication" [3]. In the previous epoch a journey or travelling was the lot of the elect, as noted by S.A. Korolkova and A.P. Naumova, however, today tourism has become a mass phenomenon in which the largest segments of population are involved. Another specific feature of the 21st century's tourism is its global character. More and more people tend to travel outside their country to visit various tourist attractions of other states [4]. A thirst for change of places and new impressions popularized in global media, the purpose of which is to promote regional branding, contributes to growth in global mobility. At present, all segments of the tourism industry demonstrate an increase in information flows providing the progress of international tourism as well as the increased attractiveness of the regions for foreign tourists. In this regard, providing a multilingual format for the information and advertising materials including most texts of tourism discourse becomes highly relevant. The texts of the tourism discourse creating positive, attractive image of the destination in the collective imagination of the linguistic community implement the important task of branding the regions.

\section{Current state of the problem}

It should be noted that the issues of intercultural and translational aspects are very important for the study of tourism discourse. These aspects involve studying the translation problems, strategies and technologies, as well as their peculiarities. The language component of the tourism discourse texts is extremely important. So back in 1996, an American scientist Graham Dann claimed: «so pervasive and essential is the language of tourism that, without it, tourism itself would surely cease to exist. In the absence of a sociolinguistic basis, the world's largest industry would simply grind to a halt, and we would all remain at home» [5]. In his opinion, the language in tourism is a form of manipulation and social control: the tourist's interest in the destination is created via linguistic forms, and positive modeling of reality is their main task. They are the ones that turn unknown and remote area into an attractive and trendy tourist attraction, which is sure to be visited. In other words, the tourist visits the places, which she/he has already visited throughout the language; thus, this suggests that the journey begins not at the moment of physical departure,

* Corresponding author: novozilova@volsu.ru 
but while reading the texts about the tourist destination, when the thought images of this area are formed.

In recent years, linguistic characteristics and peculiarities of translation in the tourism discourse have been actively studied by linguists of different countries (see, for example: $[6,7,8,9]$ ).

Such studies appear to be of current interest, as the result of linguistic analysis of multilingual tourism resources can be taken into account by their designers and developers, which, as shown by A.A. Gureeva, contributes to improving the quality of the language presentation of information about a particular tourist service, object, city, etc., and will result in their greater popularity among tourists and, thus, increasing economic profit [10].

Understanding translation as a cross-cultural phenomenon has been universally recognized, since one translates not from language into language, but from language + culture into language + culture according to J-R. Ladmiral and E. Lipiansky [11]. In other words, translation is always a correlation between the language and culture of two interacting linguistic societies, whereas the translator is not a passive mechanism of recoding text from one language into another, she or he is an active participant in the translation process. It is she/he that is considered to be the "conductor" through the lingua-cultural barrier, the mediator that is able to meet the expectations of both the sender of the text and the recipient belonging to the various lingua-cultures. Translation in the field of tourism is a specific intellectual activity, providing positive contact between the culture of a tourist destination country and a tourist who is a product of a different culture and another language.

The translator applying language means creates the attractive reality of the tourist destination and promotes the tourist brand of the region. In addition to historical, cultural, natural and other monuments and attractions, the important component of the tourism industry is accommodation, and a well-designed hotel website also contributes to creating positive brand of the region.

\section{Research objectives and methodology}

This article is devoted to understanding translatological problems, revealed after translation analysis of the materials of hotel websites as well as to identifying the effective translation strategies while presenting information about hotels in a multilingual form. When preparing a trip choosing a hotel plays an important role. While doing it, a potential guest refers to the information posted on the websites of various hotels. That is why, it should be highly informative, concise, and attractive at the same time. However, a technically flawless website with a bright design and a great amount of useful information is not a guarantee that this very hotel will be chosen by a potential guest. Fascinating language form of presenting website content becomes an essential key to success. As the evidence from practice shows it is often not considered by hoteliers when providing content for the website, aimed at foreign guests that either do not speak a foreign language, or speak it at a level that does not allow them to acquire provided information easily. Hotel owners do not always pay attention to the facts that are obvious for a professional translator: it is the right and suitable word that turns faceless and unfamiliar place (in our case hotel) into an attractive tourist choice, it is the correct language form that will make a potential visitor act, i.e. to reserve a hotel.

Marketing and advertising specialists have long known that information is always easier to perceive through emotions, especially positive. However, not applying to professional translators hoteliers obtain texts of rather doubtful quality, which do not appeal to the target audience. Therefore, hotels lose potential visitors only because the latter cannot find or acquire necessary information on the websites of hotels. High-quality translation of the website contributes to the fact that the hotel will be in demand among potential customers from different countries. Large hotels always translate their website into several languages, because the more localization languages are used on the website, the greater the number of people will be able to come to it when entering search queries in their native language. Consequently, one way to expand the client base is to translate the main sections of the website.

At the same time, it is impossible to ignore the fact that "when translating the texts of hotel websites there are certain communicative and linguistic norms and pragmatic settings" [12]. Potential guests visiting the website, which says about lush greenery, rich blue ocean, picturesque landscapes and beaches with golden sand might imagine colorful paintings and, perhaps, decide in favor of this hotel.

Translation of tourist content in general and hotel websites in particular is not a mechanical code-switching from one language to another, but its adequate localization, which is understood by linguists as the maximum focus on potential recipients and pragmatic adaptation of the text to their linguistic peculiarities and national and cultural specifics [13; 14]. It involves, firstly, focusing on the information relevant for a foreign tourist, eliminating unnecessary details and communicating all emotionality and expressive colouring, peculiar to the texts of hotel websites.

The data for our research have been taken from English, French and Russian-language websites of hotels; their translations are taken either from the official websites of the hotels or are executed by the authors of the article within their professional activity. Within translatological analysis, we have considered translation from English and French into Russian, revealed the errors, identified and suggested the effective solutions which can be called highly professional and exemplary in terms of translation strategy.

\section{Results and discussion}

Now, let us analyze the examples of translated texts from the hotel websites.

Source text: London has gained a distinguished new landmark in the form of a graceful and historic luxury 
hotel. Perfectly positioned in the heart of London, Corinthia Hotel is just steps from Trafalgar Square, Embankment, Westminster and Covent Garden and a few minutes from Mayfair and The CityVast lobbies, high ceilings, natural light and spectacular views have been combined with cutting-edge design to create iconic public spaces, beautifully appointed rooms, luxurious suites and stunning penthouses. Some of the world's leading designers have made their mark on Corinthia with stylish destination bars, speciality restaurants, London's largest and most luxurious spa and wellness centre and 295 rooms, suites and penthouses that will take your breath away.

https://www.corinthia.com/en/hotels/london/destinati on/location

Translation into Russian: В Лондоне появилась новая достопримечательность в личе величественного роскошного отеля. Идеально расположенный в самом сердие города, отель «Коринтия Лондон» находится в нескольких шагах от Трафальгарской площади, Вестминстера $и$ Ковент-Гардена. Мэйфэр и Сити также находятся в пределах досягаемости

Просторные вестибюли, высокие потолки, естественное освещение $u$ потрясающие виды наряду с ультрасовременным дизайном отличают традиционные места общественного пользования, элегантные номера и роскошные пентхаусы.

Несколько ведущих мировых дизайнеров работали над созданием стильных баров, специиализированных ресторанов, крупнейшего в Лондоне центра СПА и здоровья и более, чем 250 захватывающих дух номеров и пентхаусов.

https://www.corinthia.com/ru/hotels/london/destination/1 ocation

The original text in English involves a large number of thematically oriented vocabulary items used: a graceful and historic luxury hotel, perfectly positioned in the heart of London, vast lobbies, high ceilings, natural light, spectacular views, cutting-edge design, beautifully appointed rooms, luxurious suites, stunning penthouses; rooms, suites and penthouses that will take your breath away, etc.

Due to the choice of emotive adjectives and illustrative comparisons, the translator managed to preserve the imagery and expressiveness of the original text: величественный роскошный отель, идеально расположенный в самом сердие города, просторные вестибюли, высокие потолки, естественное освещение, потрясающие виды, ультрасовременныи дизайн, элегантные номера, роскошные пентхаусы, захватывающие дух номера and пентхаусы, etc.

The translator used adequate equivalents and several transformations. So, when translating the phrase $a$ graceful and historic luxury hotel (literally изящный $и$ исторический роскошный отель теaning "Elegant and historic luxury hotel") the translator used the omission and did not translate the adjective historic, which made the translation into Russian more successful and not overloaded with the attributes.

In the second sentence of the phrase в самом сердие города (in the source text: in the heart of London) proper name London was replaced by the translator with the lexeme город (literally translated: the city) in order to avoid repetition with the previous sentence. The translator added definitive pronoun caмbiŭ meaning "the most" which in the Russian language in combination with the noun has an emphatic function and emphasizes the utmost proximity to the described object, and also typically used in the phrase в самом сердие города (literally translated: in the very heart of the city).

When translating the sentence Vast lobbies, high ceilings, natural light... the translator used a syntactic transformation, avoiding the use of an infinitive construction not peculiar to the Russian language.

Syntactical transformations are also used for translation of the last sentence. Thus, the clause that will take your breath away is replaced by a participial phrase захватываюших дух, which appears to be correct, as a dependent clause would be stylistically unsuccessful solution in a Russian sentence.

The part of the main sentence have made their mark on Corinthia with stylish destination bars has been translated with the help of lexical transformation, thus, the translator has chosen stylistically more neutral variant работали над созданием стильных баров (literally translated: worked on creation of stylish bars) and used the omission, eliminated the name of the hotel, because it seems redundant, due to the context it is clear that stylish bars, specialized restaurants are located in the mentioned hotel.

The translated text is larger than the original text, due to the language peculiarities of the Russian language (in comparison with English Russian has longer words), but it fully meets all the criteria of quality translation: there are no language errors, communicative norms are observed, pragmatic attitudes are communicated, they are to create the most vivid image of the destination and attract potential visitors.

Translation strategy (elimination of redundant information while preserving emotiveness and expressiveness of the text) is realized by using several translation techniques. Considerable attention is given to syntax, because it is the structure of the sentence that demonstrates the translator's professional proficiency in grammatical transformations, the ability to apply them appropriately and reasonably, in accordance with the norms of the target language.

Thus, the chosen translation strategy - preservation of a pragmatic component of the original text (while the text form being conventional to the new culture) ensures the preservation of communicative and pragmatic function of the text in the new lingua-cultural space, and, consequently, performs its "commercial" task, i.e. to increase the popularity of the hotel and increase the number of customers. The translation of this text shows that a professional translator, clearly understanding the task, having a well formed operational competence, is able to create a text that will implement its main function to attract new customers.

However, most translated texts do not meet many requirements: they have language, speech, pragmatic and meaningful errors. Analyzed examples show either the use of machine translation or the lack of professionalism 
of the translator. Text containing errors is unlikely to create an attractive image of the hotel. Language errors (grammatical, spelling, punctuation), as well as violation of stylistic norms, are found in many translated texts. Of special annoyance are obvious spelling mistakes, which provide evidence of amateur's work, with lack of knowledge but claiming to be a translator.

Thus, on a website of the four-star Hotel Le Cep, Beaune (http://www.hotel-cep-beaune.com/fr/), one of the tourist centers of Burgundy, in the localized Russian version there are such spelling errors: "подобр $\boldsymbol{O}_{\text {нные, }}$ требоватеЛных, гостеприЙ мном, расположеНьй, тренЕровок, предлОгаются".

It is certainly true that these errors do not violate the understanding of the text, but they negatively affect the consumer's expectations. Here are a few more examples of translations from the websites of English and French hotels illustrating the violation of lexical compatibility and grammatical coordination, which is caused by the loan translation of the source text.

Table 1. Examples of loan translation.

\begin{tabular}{|c|c|}
\hline Source text & Translation into Russian \\
\hline $\begin{array}{l}\text { 1. The exclusive is } \\
\text { included } \\
\text { http://profi.travel/uploads/ } \\
\text { ckeditor/Catalogue_Bahia. } \\
\text { pdf) }\end{array}$ & $\begin{array}{l}\text { эксклюзивное включено } \\
\text { (предлагаемый перевод: } \\
\text { эксклюзивные } \\
\text { удобства и услуги) }\end{array}$ \\
\hline $\begin{array}{l}\text { 2. L'hôtel ... entièrement } \\
\text { dévoué à la qualité de vos } \\
\text { nuits et de votre séjour } \\
\text { http://www.hotel-cep- } \\
\text { beaune.com/fr/ }\end{array}$ & $\begin{array}{l}\text { Отель ... полностью } \\
\text { посвящен тому, чтобь } \\
\text { ваш отдых прошел } \\
\text { здесь незабываемо }\end{array}$ \\
\hline $\begin{array}{l}\text { 3. vous découvrirez les } \\
\text { 1001 détails qui } \\
\text { contribuent au charme } \\
\text { unique } \\
\text { http://www.hotel-cep- } \\
\text { beaune.com/fr/ }\end{array}$ & $\begin{array}{l}\text { вbl откроете } 1001 \\
\text { деталь, которье } \\
\text { вносят свой вклад в } \\
\text { неповторимое } \\
\text { очарование }\end{array}$ \\
\hline $\begin{array}{l}\text { 4. Nous avons été élus } 4 \\
\text { fois parmi les } 500 \\
\text { Meilleurs Hôtels du } \\
\text { Monde } \\
\text { http://www.hotel-cep- } \\
\text { beaune.com/fr/ } \\
\end{array}$ & $\begin{array}{l}\text { Mыл были избраны } 4 \\
\text { раза среди } 500 \text { лучших } \\
\text { отелей в мире }\end{array}$ \\
\hline $\begin{array}{l}\text { 5. Accessible directement } \\
\text { depuis l'Hôtel en peignoir } \\
\text { http://www.hotel-cep- } \\
\text { beaune.com/fr/ }\end{array}$ & $\begin{array}{l}\text { Доступный } \\
\text { непосредственно } \\
\text { отеля в халатах }\end{array}$ \\
\hline
\end{tabular}

All the examples given include loan translation; here it is structural borrowing of the phrases from the original sentence and use of vocabulary meanings of the words, which results in violating the pragmatic component.

It is also worth noting that in these examples with grammatical correct structure lexical compatibility is violated, and it leads to internal rejection of the text, when the semantic content is understood by the recipient, but the form does not correspond to the usage of the target lingua-culture, i.e. it does not meet the expectations of the new lingua-culture community.

However, in the second example, the translator managed to successfully apply the necessary translation transformation: replacing the participial construction with the subordinate clause as well as lexical generalization la qualité de vos nuits et de votre séjour with the neutral phrase ваш omdbыx (literally translated: your rest) concurrently having compensated a pragmatic loss by the introduction of an adverb with semantics of hyperbole with positive evaluation незабываемо (literally translated: unforgettable).

Such errors indicate that the translation has been performed not by a professional, by a "random" translator, who undertakes a task with a foreign language at the user's level, or by an incompetent translator, who uses automatic translation (Google-translator, Yandextranslator, etc.) editing extremely bad. However, in both cases, potential recipients obtain translations that do not conform to the necessary conventions of the text, do not perform their marketing function and negatively affect the overall perception due to the quality of the target language.

Let us consider another example, involving typical and most frequent errors (violation of lexical compatibility and syntax), but at the same time there are also correct translation solutions:

Table 2. Example of translation from French.

\begin{tabular}{|c|c|}
\hline Source text & Translation into Russian \\
\hline $\begin{array}{l}\text { L'établissement } 4 \text { étoiles } \\
\text {.. affilié aux prestigieux } \\
\text { «Small Luxury Hotels of } \\
\text { the World», Châteaux } \\
\text { Hôtels Collection } \\
\text { http://www.hotel-cep- } \\
\text { beaune.com/fr/ }\end{array}$ & $\begin{array}{l}\text { «Этот } 4 \text { звездочный } \\
\text { отель присоединен к } \\
\text { престижной } \\
\text { международной сети } \\
\text { отелей ... включающцей } \\
\text { некоторые из лучших } \\
\text { отелей в мире ...» } \\
\text { http://www.hotel-cep- } \\
\text { beaune.com/fr/ }\end{array}$ \\
\hline
\end{tabular}

Thus, we can consider generalization to be a successful solution, here generalization implies replacing the name of the International Association of luxurious local Small hotels of Deluxe Level (the source text contains the name of the association first in the original English language, and then translated into French) by a neutral phrase престижной международной сети отелей (literary translated: prestigious international hotel chain). Such decision is justified in this communicative situation and does not distort the cognitive information of the text. However, the translator has made an error: the prepositional phrase is used, where it is not needed, so the stylistic, as well as lexical and grammatical norms of the sentence structure are violated due to the redundancy.

In this case, we can suggest the following: отель входит в международную сеть престижных отелей. In the Russian language instead of присоединен $\kappa$ (literary translated: attached to) it is usually used 
входит в ... сеть отелей (literary translated: is a part of/ is a member of... hotel chain).

A significant error for hotel advertising texts is translator's ignorance of the standard wording, accepted for the designation of one and the same phenomenon in different lingua-cultures. On the translated websites of foreign hotels there are such links as более (literary translated: more) instead of подробнее (literary translated: more details) and возвращение (literary translated: return) instead of назад (literary translated: back). The addressee of the text will guess what it is about, but he or she is unlikely to have confidence in this hotel. The recipient of advertising texts should not make additional intellectual efforts in order to penetrate into the content transmitted by unusual language means, he/she has its own horizon of expectations, which translated texts should meet. According to the fair remark of D. Guadek, "Translation is not just a simple transition from one language to another: It always requires the full adaptation of the source text to a different audience, which has different habits, other tastes, a different way of thinking and other behavior. The different audience should perceive the translated text as if it was originally created by the representative of its culture" [15]. Here is an example that clearly demonstrates that professional translation skills are not equal to the simple knowledge of the language. As already mentioned, a professional translator requires the ability to create text that meets the expectations of the foreign recipient, transforming the source text in accordance with the usage and the language norm.

Table 3. Examples of translation from French.

\begin{tabular}{|l|l|}
\hline Source text & Translation into Russian \\
\hline «Il (groupe Bernard & «Они (группа Bernard \\
Loiseau) offre également & Loiseau) предлагают 70 \\
la possibilité de déguster & различных вин, которые \\
70 vins au verre !» & можно заказать в \\
http://www.hotel-cep- & бокалах!» \\
\hline beaune.com/fr/ & \\
\hline
\end{tabular}

The example demonstrates a logical and grammatical error, i.e. the matter concerns a group Bernard Loiseau, which is the owner of the hotel restaurant, the translator uses the pronoun they, which leads to a semantic error. Further, in the same example the translator applies an adequate lexical transformation, but the result will more likely cause a smile of a Russian-speaking recipient, than a desire to get to this restaurant.

The following translation can be offered as an option: Владельцы отеля позаботились о том, чтобы у вас была возможность продегустировать в баре 70 сортов различных вин. (literary translated: The owners of the hotel took care that you had the opportunity to taste in the bar 70 varieties of various wines).

Of course, it is impossible not to mention the classic errors associated with "false friends of the translator", which are inevitably found in the hotels' translated texts.
Table 4. Examples of translation from French.

\begin{tabular}{|c|c|}
\hline Source text & Translation into Russian \\
\hline $\begin{array}{l}\text { "Un accueil privilégié»" } \\
\text { http://www.hotel-cep- } \\
\text { beaune.com/fr/ }\end{array}$ & $\begin{array}{l}\text { "Привилегированный } \\
\text { прием» }\end{array}$ \\
\hline $\begin{array}{l}\text { "Une fidélité et une } \\
\text { loyauté qui témoignent } \\
\text { d'un respect réciproque» }\end{array}$ & $\begin{array}{l}\text { «Такая лояльность } \\
\text { является } \\
\text { свидетельством }\end{array}$ \\
\hline $\begin{array}{l}\text { http://www.hotel-cep- } \\
\text { beaune.com/fr/ }\end{array}$ & $\begin{array}{l}\text { взаимного уважения } \\
\text { между Lе Сер и его } \\
\text { работниками» }\end{array}$ \\
\hline
\end{tabular}

In the first example, the adjective привилегированный (literary translated: privileged), which is a linguistic borrowing from the French language, acquired a different meaning in Russian comparing to that one the adjective priviligie is used with in the French language.

And in this case, it would be more correct to use the combination of adjectives особый персональный прием (literary translated: special personal reception).

Let us consider the second example with a similar error: The noun лояльность (literary translated: loyalty) in the Russian language has a different meaning, and it would be more correct to choose the word постоянство (literary translated: constancy) оr верность (literary translated: fideliy) which completely conveys the meaning of the French unit Loyauté in this context.

It is worth pointing out that the level of terminology competence of the translator is of great importance. A professional should be familiar with terminology of the subject area in which he or she works, or at least should be able to work with different sources to find the required unit.

The following fragment of the section СПА услуги (literary translated: Spa services) can be cited as a negative example of the lack of an interpreter's professionalism.

Table 5. Example of translation from French.

\begin{tabular}{|l|l|}
\hline Source text & Translation into Russian \\
\hline $\begin{array}{l}\text { «Lit de flottaison» } \\
\text { http://www.hotel-cep- } \\
\text { beaune.com/fr/ }\end{array}$ & $\begin{array}{l}\text { «Кровать с эффектом } \\
\text { парения на волнах» }\end{array}$ \\
\hline
\end{tabular}

The description of this service, of course, does not concern, кровать с эффектом парения на волнах (literary translated: bed with the effect of soaring on the waves), and the very fashionable recently "floating" procedure.

The text on hotel website is a marketing text, the main task of which is to attract new customers. Thus, in this situation, the translator's work is influenced not so much by the internal parameters of the text, but by external characteristics, which may require radical adaptation of the text.

The cultural and manipulative components of such texts define all actions of the translator. Performing this 
task becomes possible only on condition of following the competently chosen strategy of translation, knowledge of standard language wording and absence of various language and speech errors in the text, leading to the fact that a potential user can leave the website of the hotel, not finding it sufficiently clear or readable and therefore trustworthy.

\section{Conclusion}

The main problem of the twenty-first century in the translation industry, as well as in the tourism sector, is that the number of people who know foreign languages is growing. This is undoubtedly a positive factor, as tourists can get acquainted, communicate with representatives of the country where they come to rest in their native language or, at least, using the simplified English Language as "lingua franca" of our time. However, there is a devaluation or depreciation of professional translator's work: everyone who knows language thinks she/he can translate.

This activity results in the texts written in the target language, which in terms of the content practically do not distort the original text, but in general are not highquality professional translation, as while preserving most of cognitive information they lose functional-pragmatic information. A peculiarity of the translated text of tourism discourse is that it must represent space unfamiliar and alien to the culture of the recipient in the form of a habitual cultural phenomenon.

That is why all linguistic forms should be familiar to a foreign recipient, a translator must carefully choose between stereotyped, cliched formulas and vivid metaphors and epithets. The translator's strategy while working on translation of marketing texts created to attract the maximum possible number of potential users (guests) of other lingua-society should be aimed at creating such text which will be perceived by a potential buyer not as a translation of a foreign-language text, but as the original text. Therefore, the following competencies of a professional translator become in demand: creativity, native speaker level and proficiency to be able to use idiomatic expression of language space, as well as clichés and terminology of many associated spheres, for example, cosmetology; in addition, inexhaustible cultural stock and wide existential competence are significant.

The translated text of the hotel website should not only accurately and adequately convey the content of the original text, but also demonstrate the advantages of the hotel in the form comprehensible to the users (guests) of the website. In most cases, the translation strategy for this type and genre of the text is to create a new text with certain stylistic markers and figurative characteristics, which requires changing the shape and structure of the original text.

The reported study was funded by the Russian Foundation for Basic Research (RFBR), the Administration of the Volgograd Region, Project No. 17-14-34001 Regional Tourism as Factor of Discourse and Translation Technology Formation:
Nominative and Communicative-Pragmatic Conventions of Branding Texts (Volga Lands in the History and Culture of Russia 2018 Regional Contest, Volgograd Region)

\section{References}

1. A.A., Dorofeeva, A.A., Dorofeev, Language Discourse in the Social Practice, 80-86 (2015)

2. V.A. Mityagina, Communicative Actions in the Tourist Discourse. Foreign Languages in Tertiary Education 4, 88-97 (2009)

3. E.Yu. Novikova, Journal of Voronezh State University. Linguistics and Intercultural Communication 1, 53-57 (2015)

4. S.A. Korolkova, A.P. Naumova, Guide translation: the complexity of cultural transfer, Linguistic and translatological logistics of the multilingual tourist Internet resource (Volgograd State University, Volgograd, 2016)

5. G. Dann, The language of tourism (CAB International, 1996)

6. M. Agorni, Questions of mediation in the translation of tourist texts, Altre modernità. Numero Speciale Confini mobili: lingua e cultura nel discorso del turismo (2012), URL: https://riviste.unimi.it/index.php/AMonline/article/vi ew/1963 (date of access: 16.04.18)

7. M. Guidère, Publicité et Traduction (L'Hartmattan, 2000)

8. V. A. Mityagina, E. Yu. Novikova, T. Yu. Makhortova, I. D Volkova, ASSEHR, Proceedings of the 7th International Scientific and Practical Conference "CILDIAH 2017" 97, 320-325 (2017)

9. J. Potočnik Topler, Language, discourse and communication in globalized tourism, Literature, language and culture influenced by globalization: ("East West" Association for Advances Studies and Higher Education GmbH, Vienna, 2015)

10. A.A. Gureeva, Proceedings of the 3rd All-Russian Scientific Conference "Branding as a communicative technology of the 21st century", 128-131 (2017)

11. J.-R. Ladmiral, E. M. Lipiansky, La Communication interculturelle (Armand Colin, Paris, 1989)

12. A.A. Novozhilova, Modern Research of Social Problems (digital journal) 8 (52),138-149 (2015) DOI: http://dx.doi.org/10.12731/2218-7405-2015-811 (date of access: 16.04.18)

13. F. Austermühl, Training translators to localize (Auckland: University of Auckland, 2015)

14. A. Pym, Website localization, The Oxford Handbook of Translation Studies ed. by K. Malmkjaer, K. Windle, 410-424 (Oxford University Press, 2011)

15. D. Gouadec, Le traducteur, la traduction et l'entreprise (AFNOR, Paris, 1989) 